\title{
Individualismo, autorreconhecimento e convívio
}

Claudionei Vicente Cassol*

O professor François de Singly, nascido em 1948 na cidade francesa de Dreux, catedrático da cadeira de Sociologia na Faculdade de Ciências Humanas e Sociais da Universidade de Sorbonne, em Paris, Diretor do Centro de Estudos e Pesquisas sobre as Relações Sociais, especialista da família, das relações privadas e do adolescente, publica, em 2003, na França, pela Editora Armand Colin, Les uns avec les autres. O livro é traduzido em Portugal pelo Instituto Piaget e publicado, em 2006, como Uns com os Outros: quando o individualismo cria laços, com 268 páginas organizadas em cinco capítulos. Os títulos, geralmente seguidos de interrogações acerca da discussão, têm expressivos subtítulos sintonizados com a proposta temática da possibilidade instituinte de laços sociais a partir do "individualismo". A versão portuguesa tem 15 páginas de introdução, dividida em subtítulos, e 8 páginas de conclusão, índice de nomes contendo 4 páginas e sumário, ao final, após as 15 páginas de bibliografia. Trata-se de obra sociológica de leitura fluente, agradável, com incursões para a filosofia e a psicologia.

Uns com os Outros segue, conscientemente, na oposição das tematizações negativas acerca dos tempos atuais que visualizam apenas carências/deficiências e superficializações para as fortes tendências individualistas. Apresenta, justamente dessa dimensão subjetiva/individual/pessoal, característica profunda da pós-modernidade, possibilidades constitutivas/autoconstituintes para o indivíduo e para os laços sociais. Com fonte ontológica, a obra ensina que "o direito de amar" e os outros direitos, embora contenham compreensões diferenciadas, são atitudes/ações comuns. Ainda que os laços careçam de permanência, o amor perdura, assim como o aprender, o desejo de saber algo. Na renúncia a um laço, a um vínculo permanente, ainda há a permanência da busca por um novo vínculo, uma nova possibilidade

Recebido em 27/04/2018 - Aprovado em 19/02/2019

http://dx.doi.org/10.5335/rep.v26i2.9411

Mestre em Educação pela Unisinos, São Leopoldo, RS. Doutorando em Educação nas Ciências pela Unijuí, ljuí, RS. Professor no CE Dr. Dorvalino Luciano de Souza e na Universidade Regional Integrada do Alto Uruguai e das Missões - Campus de Frederico Westphalen, RS, Brasil. E-mail: cassol@uri.edu.br 
de conexões. É possível, então, salvar o mundo. Para isso, é urgente desenvolver uma "visão positiva do mundo moderno", possível de ser pensada pela sociologia a partir do indivíduo. “O ‘nós' deve respeitar os 'eu' que o compõem”. Os indivíduos não mudam a tal ponto que a natureza social, o 'nós' do privado, difira completamente do 'nós' do público. Dessa forma, "indivíduos individualizados" não significa somente gosto/prazer/satisfação de estar só; o "elo social" está "composto por fios menos sólidos que os fios anteriores, mas engloba, nitidamente, muito mais fios". É esse o indivíduo individualizado que pode, simultaneamente, definir-se como membro de um grupo e como dotado de uma personalidade independente e autônoma.

Compreensões como "enclausuramento identitário", característica das "sociedades holísticas", devem ser substituídas pelo "desenraizamento", pela "não pertença”, porque o papel republicano - e a escola/a educação tem lugar aí - não é condenar cada um a carregar o peso das suas origens e de seus determinismos, mas ensinar a cidadania, dimensão essencial da modernidade democrática. Para a educação desses tempos, Singly ensina que eles são muito mais de "ventos" e "velas" do que de cordas. Essa ação educacional viabiliza o desenvolver/o inventar de novas raízes. Raízes precisam ter a dinâmica da "âncora" e da "tenda": podem ser lançadas/armadas e alçadas/desarmadas a qualquer momento. $\mathrm{O}$ "indivíduo contemporâneo reivindica o direito à porta aberta, o direito a descomprometer-se, mas não aprecia a interdição de compromisso". Portanto, ele quer ter prerrogativas, porque a individualização não suprime o social, apenas constitui uma das suas formas. Na apresentação do "eu em primeiro lugar", de forma alguma há declaração de egoísmo moral. Singly significa, apenas, que nenhuma dimensão social da identidade, atribuída e reivindicada, pode ser a trave-mestra do edifício pessoal.

A sociedade moderna pode ser compreendida com duas dimensões: "Sociedades Holistas" e "Sociedades Individualizadas". Conceitos muito próximos do que compreende Zygmunt Bauman (1925-2017) com "Modernidade Sólida" e "Modernidade Líquida". No entanto, nem tempos sólidos nem tempos líquidos podem desconsiderar as subjetividades, os "eus", as identidades, porque é desse lugar que novos laços/novas conexões podem ser construídos, não como amarras, cercas, mas convívio/relação/tendas. É possível aprender, na análise de Singly, o quanto a liberdade decorre não da ausência de limitações, mas da escolha das limitações assumidas e recolocadas num projeto de vida/existência/convivência.

Os lapsos de grafia e concordância resultantes, talvez, da tradução não invalidam a profundidade com que Singly aborda a temática do individualismo ou do indivíduo/da individualização/da subjetividade. O autor desenvolve suas afir- 
mações, de alguma forma, tornando-as, seguidamente, absolutas/deterministas, o que pode se constituir risco, porque inviabiliza alternativas que, inclusive, teriam a potencialidade/viabilidade a partir do próprio indivíduo. Então, apresentam-se contraditórias no conjunto das compreensões de Singly, inclusive porque é ele próprio quem escreve: "A identidade fluida é necessariamente multidimensional". O modo como Singly compreende a individualidade, a subjetividade, denominando-a de "individualismo", talvez aponte para uma radicalidade não condizente com uma possibilidade paradigmática da atualidade/contemporaneidade, expressa pela ambivalência/plurivalência, ou que tenha consciência das várias vias possíveis, nunca únicas, de realização do "convívio". Contudo, essas questões não invalidam a hermenêutica, a filosofia social e a análise do indivíduo na relação com a sociedade/comunidade que eleva o debate desenvolvido na obra à condição de raridade, especialmente porque, na contracorrente das tematizações/compreensões pós-modernas/contemporâneas, Singly visualiza a possibilidade de construção de laços sociais e das suas manutenções, a partir do "individualismo". É no viver as prerrogativas/as demandas/as escolhas, com autonomia, e na busca pela satisfação de seus desejos, realizando a sua vontade ontológica, que o indivíduo/o sujeito reconhece a necessidade do outro. Por isso busca em Anthony Giddens o conceito de "segurança ontológica”, para justificar que ainda paira, nos indivíduos individualizados, o desejo de estar-com/de convívio.

Ao escrever que "o reconhecimento da alteridade é o horizonte da democracia avançada, desde que não se perca de vista o reconhecimento da igualdade”, Singly indica a necessidade de manutenção de alguma regulação, tanto no âmbito privado/pessoal quanto na dimensão do coletivo/social, para assegurar proteção, atenção personalizada, respeito mútuo e igualdade de oportunidades. Essas atitudes formam, ou deveriam formar, o quadro da educação e da vida comum no seio de uma sociedade democrática, porque preservam a dignidade humana. Se a educação opera no sentido da viabilização do respeito à diversidade, à individualidade e à dignidade humana, lança, dessa ação/dessa práxis, as cepas da diversidade e indica o diálogo como caminhos possíveis da solidariedade/dos laços sociais. A obra indica que a "crise" do elo social é uma característica das sociedades modernas, não um defeito do modelo; é constitutiva do modelo. Quanto ao indivíduo e à sociedade/ comunidade, Singly enfatiza: “[...] o indivíduo não se realiza apenas na discussão, tem também necessidade de outra forma de relação com os outros para descobrir a sua originalidade, a sua autenticidade, a sua interioridade". Nesse sentido, “[...] 
o eu não pode ser alcançado senão pelo diálogo com um outro significativo, através da formação de relações afectivas, amorosas e de amizade”.

Uns com os Outros tematiza três formas de individualização: "O concorrencial, próprio do mercado; o relacional, próprio do afectivo; o cidadão, próprio do político", para compreender que uma "sociedade" não pode ser viável a não ser que consiga propor condições que permitam aos indivíduos individualizados viver juntos, porque cada um/cada indivíduo é único. Cada um aspira uma vida em comum. Contudo, o particular não exclui o comum, mas abre a possibilidade de constituir, via educação - formal e informal -, a "aprendizagem do descentramento", ou seja, "pôr-se no lugar do outro para saber como é que ele deve ser respeitado". Esse compromisso/reconhecimento/respeito mútuo não pressupõe nem uma relação igual de estatutos nem uma confusão das identidades, mas a relação entre "dignidade humana, identidade pessoal e identidade social”. Nesta configuração, a realização do eu exige, por um lado, um âmbito social e econômico elaborado conjuntamente com a política e, por outro, um reconhecimento mútuo das diferenças afirmadas.

\section{Referência}

SINGLY, François de. Uns com os outros: quando o individualismo cria laços. Lisboa: Instituto Piaget, 2006. 